\title{
Acidic Properties and Catalytic Activity of Titanium Sulfate Supported on $\mathrm{TiO}_{2}$
}

\author{
Jong Rack Sohn, ${ }^{\star}$ Si Hoon Lee, ${ }^{\dagger}$ Park Won Cheon, and Hea Won Kim ${ }^{\ddagger}$
}

\author{
Department of Applied Chemistry, Engineering College, Kinngpook National Lniversity, Daegu 702-701, Korea \\ - Enwronment Research Team, Research Institute of Industrial Science and Technologi, Kiningbuk, Pohang 790-330, Korea \\ 'Department of Industrial Chemistry, Kythg Il Lniversitw, Kynngsin 71 2-701, Korea \\ Received November 29, 2003
}

\begin{abstract}
Titanium sulfate supported on $\mathrm{TiO}_{2}$ was prepared by impregnation of powdered $\mathrm{TiO}_{2}$ with an aqueous solution of titanium sulfate followed by calcining in air at high temperature. For $\mathrm{Ti}\left(\mathrm{SO}_{4}\right)_{2} / \mathrm{TiO}_{2}$ samples calcined at 300 ${ }^{\circ} \mathrm{C}$, no diffraction lines of titanium sulfate are observed at $\mathrm{Ti}\left(\mathrm{SO}_{4}\right)_{2}$ loading up to $30 \mathrm{wt} \%$. indicating good dispersion of $\mathrm{Ti}\left(\mathrm{SO}_{4}\right)_{2}$ on the surface of $\mathrm{TiO}_{2}$. The acidity of the catalysts increased in proportion to the titanium sulfate content up to $20 \mathrm{wt} \%$ of $\mathrm{Ti}\left(\mathrm{SO}_{4}\right)_{2} .20 \mathrm{wt} \% \mathrm{Ti}\left(\mathrm{SO}_{4}\right)_{2} / \mathrm{TiO}_{2}$ calcined at $300^{\circ} \mathrm{C}$ exhibited maximum catalytic activities for 2-propanol delydration and cumene dealkylation. The catalytic activities for these reactions. were correlated with the acidity of catalysts measured by ammonia chemisorption method.
\end{abstract}

Key Words : Titanium sulfate supported on $\mathrm{TiO}_{2}$. Characterization. 2-Propanol dehỵdration. Cumene dealkylation. Acidic properties

\section{Intorduction}

Acid catalysis ${ }^{1.2}$ plays a key role in many important reactions of the chemical and petroleum industries, and environmentally benign chenical processes. Liquid superacids ${ }^{3}$ based on HF. which are efficient and selective at roon temperature. are not suitable for industrial processes due to separation problems tied with environmental regulations. Conventional industrial acid catalysts, such as sulfuric acid. $\mathrm{AlCl}_{3}$, and $\mathrm{BF}_{3}$, have unavoidable drawbacks because of their severe corrosivity and high susceptibility to water. Thus the search ${ }^{2.5}$ for environmentally benign heterogeneous cataly sts has driven the worldwide research of new materials as a substitute for current liquid acids and halogen-based solid acids. Among them sulfated oxides. such as sulfated zirconia, titania, and iron oxide exhibiting high thermostability. superacidic property. and high catalytic activity. have evoked increasing interest. ${ }^{2.4 .5}$ The strong acidity of zircona-supported sulfate has attracted much attention because of its ability to catalyze many reactions such as cracking alkylation and isomerization. The potential for a heterogeneous catalyst has yielded many research output on the cataly tic activity of sulfated zirconia materials. ${ }^{49}$

Sulfated zirconia incorporating $\mathrm{Fe}$ and $\mathrm{Mn}$ has been shown to be highly active for butane isomerization. catalyzing the reaction even at room temperature ${ }^{[0.1]}$ Such promotion in activity of catalyst has been confirmed by several other research group. ${ }^{12-1+}$ Coelho et $\alpha .^{15}$ have discovered that the addition of Ni to sulfated zirconia results in an activity enhancement comparable to that caused by the addition of $\mathrm{Fe}$ and Mn. It has been reported by several workers that the addition of platinum to zirconia modified by sulfate ions enhances catalytic activity in the skeletal isomerization of alkanes without deactivation when the reaction is carried out

\footnotetext{
To whom comespondence should be addressed. Tel: +82-53950-5585; Fax: +82-53-950-6594; e-mail: jrsohntatknuac.kr
}

in the presence of hydrogen ${ }^{\text {li-18 }}$ The high catalytic activity and small deactivation can be explained by both the elimination of the coke by hydrogenation and hydrogenolysis. ${ }^{16}$ and the formation of Brönsted acid sites from $\mathrm{H}_{2}$ on the catalysts. ${ }^{17}$ Recently. Hino and Arata reported zirconia-supported tungsten oxide as an altennative material in reaction requiring strong acid sites. ${ }^{4.19}$ Several advantages of tungstate, over sulfate, as dopant include that it does not suffer from dopant loss during thermal treatment and it undergoes significantly less deactivation during catalytic reaction. ${ }^{20}$

Many metal sulfates generate fairly large amounts of acid sites of moderate or strong strength on their surfaces when they are calcined at $400-700{ }^{\circ} \mathrm{C} \cdot 2.21$ The acidic property of metal sulfate often gives high selectivity for diversified reaction such as hydration. polymerization, alkylation. cracking. and isomerization. Structural and physicochemical properties of supported metal sulfates are considered to be in different states compared with bulk metal sulfates because of their interaction with supports. ${ }^{2-24}$ It came to our attention that titanium sulfate catalysts supported on $\mathrm{TiO}_{2}$ have not been reported up to now.

In this investigation. titanium oxide was prepared by a precipitation method and was used as a support. This paper describes acidic properties of titanium sulfate supported on $\mathrm{TiO}_{2}$ and its activity in acid catalysis. The characterization of the samples was performed by means of Fourier transform infrared (FTIR) spectroscopy. X-ray diffraction (XRD), differential scanning calorimetry (DSC), and surface area measurements. For the acid cataly sis. 2-propanol delydration and cumene dealkylation were used as test reactions.

\section{Experimental Section}

Catalyst preparation. The precipitate of $\mathrm{Ti}(\mathrm{OH})_{4}$ was obtained by adding aqueous anmonia slowly into a mixed aqueous solution of titanium tetrachloride and hydrochloric acid at $60^{\circ} \mathrm{C}$ with stirring until the $\mathrm{pH}$ of the mother liquor 
reached about $8 .^{25}$ The precipitate thus obtained was washed thoroughly with distilled water until chloride ion was not detected, and was dried at room temperature for $12 \mathrm{~h}$. The dried precipitate was powdered below 100 mesh. Catalysts containing various titanium sulfate contents were prepared by the impregnation of $\mathrm{Ti}(\mathrm{OH})_{4}$ powder with an aqueous solution of $\mathrm{Ti}\left(\mathrm{SO}_{4}\right)_{2} \cdot 4 \mathrm{H}_{2} \mathrm{O}$ followed by calcining at different temperatures for $2 \mathrm{~h}$ in air. This series of catalysts is denoted by the weight percentage of titanium sulfate. For example. $20-\mathrm{Ti}\left(\mathrm{SO}_{4}\right)_{2} / \mathrm{TiO}_{2}$ indicates the catalyst containing $20 \mathrm{wt} \%$ of $\mathrm{Ti}\left(\mathrm{SO}_{4}\right)_{2}$.

Characterization and catalytic study. FTIR spectra were obtained in a heatable gas cell at room temperature using Mattson Model GL6030Г, spectrophotometer. The wafers contained about $9 \mathrm{mg} / \mathrm{cm}^{2}$ self-supporting catalyst. Prior to obtaining the spectra the samples were heated under vacuum at $25-400{ }^{\circ} \mathrm{C}$ for $1 \mathrm{~h}$. Catalysts were checked in order to determine the structure of the prepared catalysts by means of a Philips X'pert-APD X-ray diffractometer, employing Nifiltered $\mathrm{Cu} \mathrm{K}_{\alpha}$ radiation. DSC measurements were performed by a $\mathrm{Pl}$-STA model $1500 \mathrm{H}$ apparatus in air, and the heating rate was $5{ }^{\circ} \mathrm{C}$ per minute. For each experiment $10-15$ $\mathrm{mg}$ of sample was used.

The acid strength of catalyst was measured qualitatively using a series of the Hammett indicators. ${ }^{26}$ The catalyst in a glass tube was pretreated at $500^{\circ} \mathrm{C}$ for $1 \mathrm{~h}$ and filled with dry nitrogen. For the determination of acid strength of the catalyst the color changes of indicators were observed by spot test. Chemisorption of ammonia was employed as a measure of acidity of catalysts. The amount chemisorbed was obtained as the irreversible adsorption of ammonia. ${ }^{2+}$ Thus the first adsorption of anmonia at $20^{\circ} \mathrm{C}$ and 300 Torr was followed by evacuation at $230^{\circ} \mathrm{C}$ for $1 \mathrm{~h}$ and readsorption at $20^{\circ} \mathrm{C}$, the difference between two adsorptions at $20^{\circ} \mathrm{C}$ giving the amount of chemisorption. The specific surface area was determined by applying the BFT method to the adsorption of nitrogen at $-196^{\circ} \mathrm{C}$.

2-propanol dehydration was carried at 160 and $180^{\circ} \mathrm{C}$ in a pulse micro-reactor connected to a gas chromatograph. Fresh catalyst in the reactor made of $1 / 4$ inch stainless steel was pretreated at $400^{\circ} \mathrm{C}$ for $\mathrm{I} \mathrm{h}$ in the nitrogen atmosphere. Diethyleneglycol succinate on Simalite was used as packing material of gas chromatograph and the column temperature was $180^{\circ} \mathrm{C}$ for analyzing the product. Catalytic activity for 2-propanol dehydration was represented as mole of propylene converted from 2-propanal per gram of catalyst. Cumene dealkylation was carried out at $250-300{ }^{\circ} \mathrm{C}$ in the same reactor as above. Packing material for the gas chromatograph was Benton 34 on chromosorb $W$ and column temperature was $130^{\circ} \mathrm{C}$. Catalytic activity for cumene dealkylation was represented as mole of benzene converted from cumene per gram of catalyst. Conversions for both reactions were taken as the average of the first to sixth pulse values.

\section{Results and Discussion}

Infrared spectra. The IR spectra of $20-\mathrm{Ti}\left(\mathrm{SO}_{1}\right)_{2} / \mathrm{TiO}_{2}$

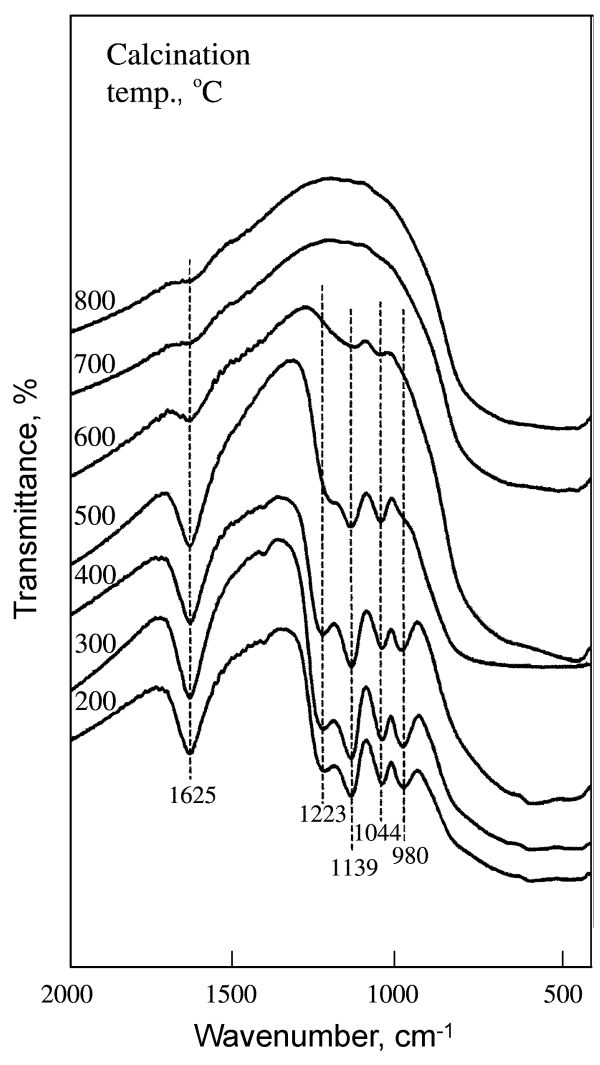

Figure 1. Infiared spectra of $20-\mathrm{Ti}\left(\mathrm{SO}_{4}\right)_{2} / \mathrm{TiO}_{2}$ calcined at different temperatures for $2 \mathrm{~h}$.

( $\mathrm{KBr}$ disc) calcined at different temperatures $\left(200-800^{\circ} \mathrm{C}\right)$ are given in Figure 1. 20- $\mathrm{Ti}\left(\mathrm{SO}_{1}\right)_{2} / \mathrm{TiO}_{2}$ calcined up to 600 "C showed IR absorption bands at 1223, 1139, 1044 and 980 $\mathrm{cm}^{-1}$ which are assigned to bidentate sulfate ion ${ }^{27}$ coordinated to the metal such as $\mathrm{Ti}^{4-}$. The band at $1625 \mathrm{~cm}^{-1}$ is assigned to the deformation vibration mode of the adsorbed water. For $20-\mathrm{Ti}_{(}\left(\mathrm{SO}_{4}\right)_{2} / \mathrm{TiO}_{2}$ calcined at $600{ }^{\circ} \mathrm{C}$, the band intensities of sulfate ion decreased considerably because of the partial decomposition of sulfate ion. However, for the sample calcined at $700-800{ }^{\circ} \mathrm{C}$ IR bands by the sulfate ion disappeared completely due to the decomposition of sulfate ion.

In general, for the metal oxides modified with sulfate ion followed by evacuation above $400{ }^{\circ} \mathrm{C}$, a strong band $d^{28-30}$ assigned to $\mathrm{S}=\mathrm{O}$ stretching frequency is observed at 1390 $1370 \mathrm{~cm}^{-1}$. In this work, the corresponding band for samples exposed to air was not found because water molecules in air were adsorbed on the surfaces of catalysts. These results are very similar to those reported by other authors. ${ }^{28-3010}$ In a separate experiment IR spectra of self-supported $20-\mathrm{Ti}\left(\mathrm{SO}_{1}\right)_{2}$ $\mathrm{IiO}_{2}$ after evacuation at $25-500{ }^{\circ} \mathrm{C}$ for $2 \mathrm{~h}$ were examined. As shown in Figure 2. an intense band at $1370-1382 \mathrm{~cm}^{-1}$ accompanied by broad and intense bands below $1250 \mathrm{~cm}^{-1}$ was observed due to the overlapping of the $\mathrm{TiO}_{2}$ skeletal vibration, indicating the presence of different adsorbed species depending on the treatment conditions of the sulfated sample..$^{29}$ At $100^{\circ} \mathrm{C}$ an asymmetric stretching band of $\mathrm{S}=\mathrm{O}$ bonds was not observed because water molecules are adsorbed on the surface of $20-\left[\mathrm{i}\left(\mathrm{SO}_{4}\right)_{2} /\right]_{\mathrm{iO}}{ }_{2} \cdot{ }^{30-32}$ At $200^{\circ} \mathrm{C}$ 


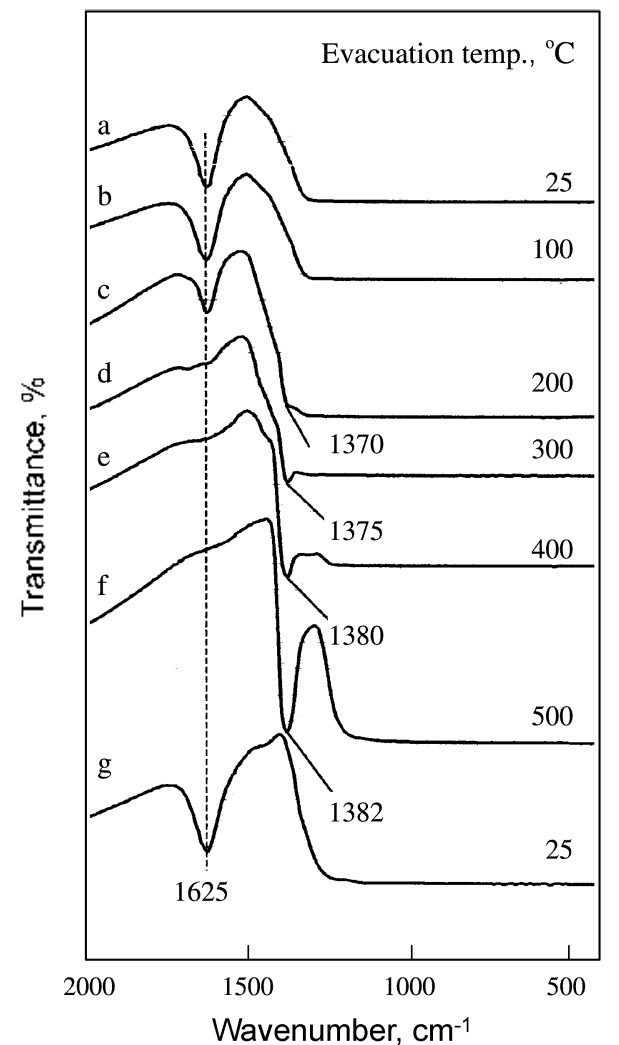

Figure 2, Intrared spectra of $20-\mathrm{Ti}\left(\mathrm{SO}_{4}\right)_{2} / \mathrm{IiO}$ evacualed at different temperatures.

the $\mathrm{S}=\mathrm{O}$ stretching band appeared as a shoulder at $1.370 \mathrm{~cm}^{-1}$. The band at $1625 \mathrm{~cm}^{-1}$ in Figure 2 is assigned to the deformation vibration mode of the adsorbed water and the band intensity decreases with the evacuation temperature. The band intensity increased with the evacuation temperature and the position of band shifted to a higher wavenumber. That is, the higher the evacuation temperature, the larger was the shift of the asymmetric stretching frequency of the $\mathrm{S}=\mathrm{O}$ bonds. It is likely that the surface sulfur complexes formed by the interaction of oxides with sulfate ions in highly active catalysts have a strong tendency to reduce their bond order by the adsorption of basic molecules such as $\mathrm{H}_{2} \mathrm{O} \cdot{ }^{76 \cdot 3.32}$ When the $20-\mathrm{Ji}\left(\mathrm{SO}_{4}\right) / \mathrm{TiO}_{2}$ sample evacuated at $500{ }^{\circ} \mathrm{C}$ was exposed to air at $25^{\circ} \mathrm{C}$, the drastic shift of the IR band from $1382 \mathrm{~cm}^{-1}$ to lower wavenumber (not shown due to the overlaps with skeletal vibration band of $\mathrm{TiO}_{2}$ ) occurred because of the adsorption of water, resulting in the appearance of adsorbed water band at $1625 \mathrm{~cm}^{-1}$ [(see rigure 2(g))]. Consequently, as shown in Figure 2 , an asymmetric stretching band of $\mathrm{S}=\mathrm{O}$ bonds for the sample evacuated at a lower temperature appears at a lower frequency compared with that for the sample evacuated at higher temperature because the adsorbed water reduces the bond order of $\mathrm{S}=\mathrm{O}$ from a highly covalent double-bond character to a lesser doublebond character.

Crystalline structure of $\mathrm{Ti}\left(\mathrm{SO}_{4}\right)_{2} / \mathrm{TiO}_{2}$. The crystalline structure of catalysts calcined in air at different temperatures for $2 \mathrm{~h}$ were checked by $\mathrm{X}$-ray diffraction. In the case of pure $\mathrm{JiO}_{2}$, most of $\mathrm{JiO}_{2}$ calcined at $400^{\circ} \mathrm{C}$ was present as anatase

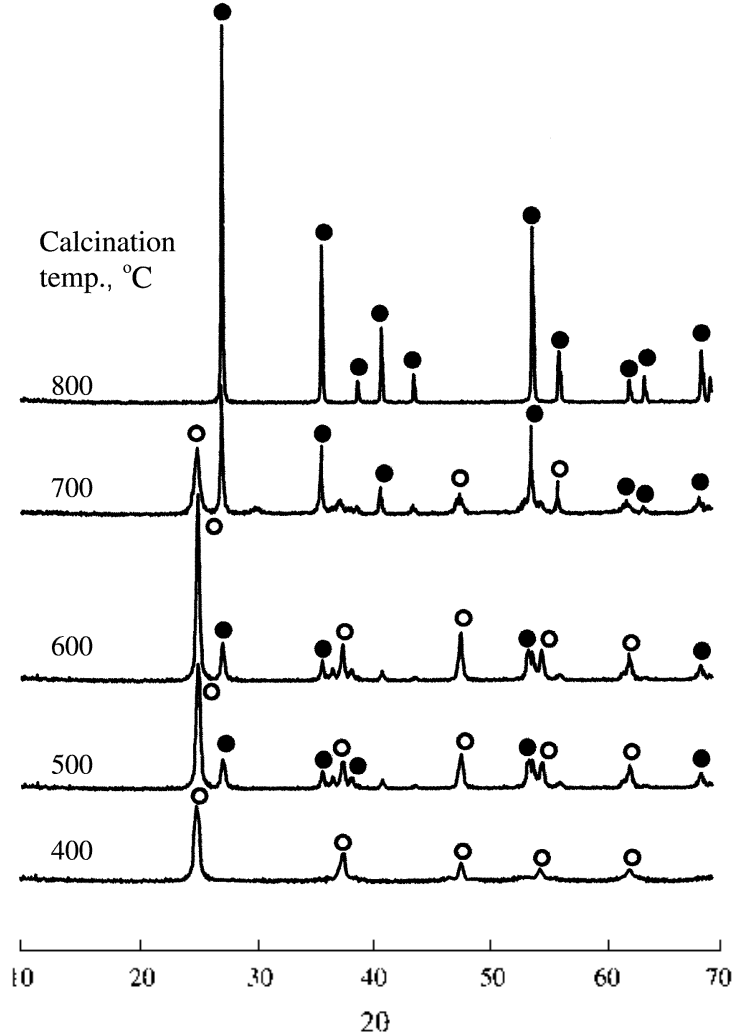

Figure 3. X-ray dilliracion patlems of $\mathrm{liO}_{2}$ calcined a different. temperatures for $2 \mathrm{~h}$ : anatase phase of $\mathrm{JiO}_{2}$; - rutile phase of $\mathrm{TiO}_{3}$.

form to X-ray diffiaction. However, as shown in Figure 3. the amount of anctase increased with increasing the calcination temperature up to $600{ }^{\circ} \mathrm{C}$, indicating that amorphous $\mathrm{TiO}_{2}$ was transformed into anatase form. From $500^{\circ} \mathrm{C}$. a tiny amount of anatase $\mathrm{TiO}_{2}$ was transformed into rutile form and the amount increased with the calcination temperature, showing the complete transformation from anatase form to rutile at $800{ }^{\circ} \mathrm{C}$. A two phase mixture of the anatase and rutile was observed at $500-700^{\circ} \mathrm{C}$.

For the 20- $\mathrm{Ti}\left(\mathrm{SO}_{4}\right)_{2} / \mathrm{TiO}_{2}$ calcined at $300-800{ }^{\circ} \mathrm{C}, \mathrm{X}$-ray diffraction data. as shown in Figure 4 , indicated only an anatase phase of $\mathrm{TiO}_{2}$ at $300-500^{\circ} \mathrm{C}$. The amount of anatase phase increased with the calcination temperature. However. at 600 ' $\mathrm{C}$ a rutile phase of $\mathrm{TiO}_{2}$ was observed due to the phase transition from anatase form to rutile. The amount of rutile phase also increased with the calcination temperature. showing only rutile phase at $800^{\circ} \mathrm{C}$ due to the complete phase transition from anatase form to rutile. No crystalline phase of $\mathrm{li}\left(\mathrm{SO}_{4}\right)_{2}$ was observed at any calcination temperature, indicating good dispersion of $\mathrm{Ii}\left(\mathrm{SO}_{4}\right)_{2}$ on the surface of $\mathrm{IiO}_{2}$ due to the interaction between $\mathrm{Ci}\left(\mathrm{SO}_{4}\right)_{2}$ and $\mathrm{TiO}_{2}$. Comparing Figure 3 with Figure 4 , it is clear that the phase transition of $\mathrm{TiO}_{2}$ in $\mathrm{Ji}\left(\mathrm{SO}_{4}\right)_{2} / \mathrm{IiO}_{2}$ sample from anatase form to rutile is considerably delayed in comparison with the pure $\mathrm{IiO}_{2}$ because of the interaction between $\mathrm{Ti}\left(\mathrm{SO}_{4}\right)_{2}$ and $\mathrm{TiO}_{2}$. In view of the $\mathrm{X}$-ray diffraction patterns, the calcination temperatures at which the rutile phase is observed initially 


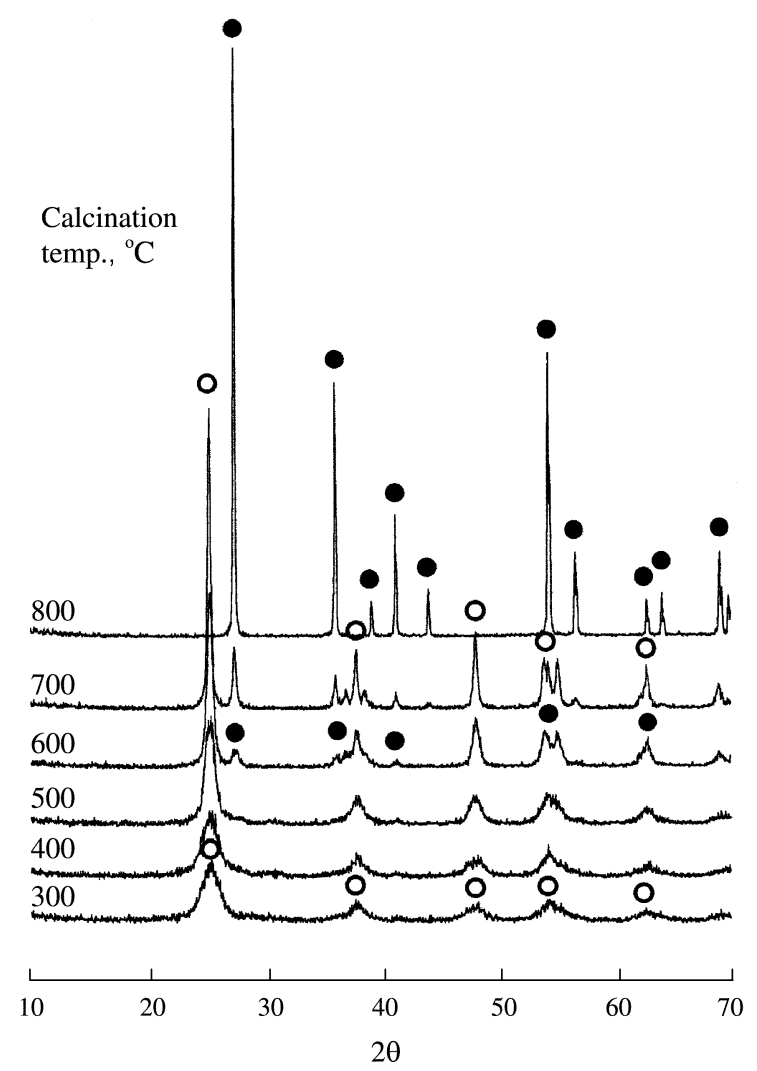

Figure 4. X-ray diffiraction patterns of $20-\mathrm{T}\left(\mathrm{SO}_{4}\right)_{2} / \mathrm{TiO} \mathrm{O}_{2}$ calcined at different temperatures for $2 \mathrm{~h}$ : . anatase phase of $\mathrm{TiO}_{2}$ : $\bullet$. rutile phase of $\mathrm{TiO}_{2}$.

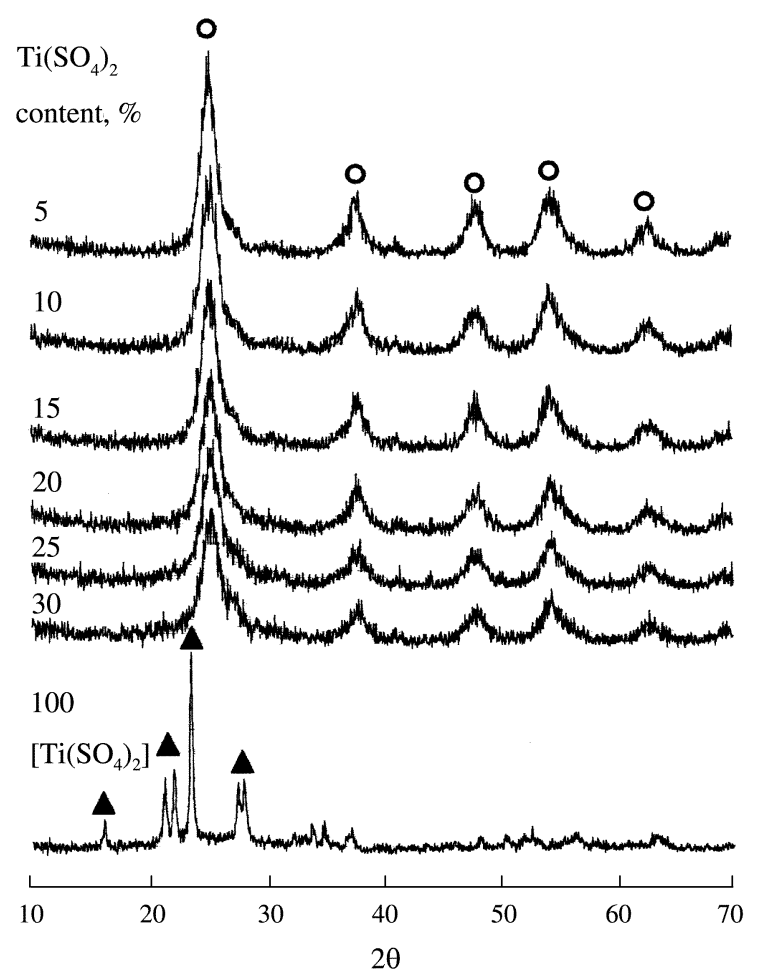

Figure 5. X-ray diffraction patterns of $\mathrm{Ti}\left(\mathrm{SO}_{1}\right)_{2} / \mathrm{IiO} \mathrm{O}_{2}$ having various $\mathrm{Ti}\left(\mathrm{SO}_{4}\right)_{2}$ contents and calcined at $300{ }^{\circ} \mathrm{C}$ for $2 \mathrm{~h}$ : $\therefore$. anatase phase of $\mathrm{IiO}_{2}: 4$. Ti( $\left.\mathrm{SO}_{4}\right)_{2}$ phase.

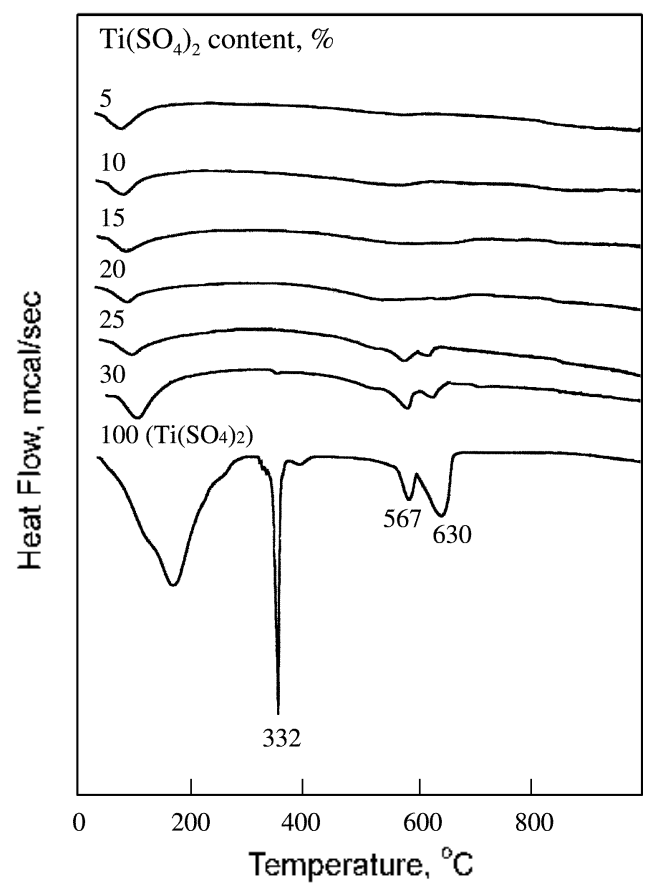

Figure 6. DSC curves of precursors for $\mathrm{Ti}\left(\mathrm{SO}_{4}\right)_{2} \mathrm{TiO}_{2}$ having diflerent $\mathrm{li}\left(\mathrm{SO}_{3}\right)_{2}$ conlents.

are $500{ }^{\circ} \mathrm{C}$ for pure $\mathrm{TiO}_{2}$ and $600{ }^{\circ} \mathrm{C}$ for $20-\mathrm{Ti}\left(\mathrm{SO}_{4}\right)_{2} \mathrm{TiO}_{2}$, respectively. That is, the phase transition temperature for 20 $\mathrm{Ti}\left(\mathrm{SO}_{4}\right)_{2} / \mathrm{TiO}_{2}$ is higher by $100^{\circ} \mathrm{C}$ than that for pure $\mathrm{TiO}_{2}$.

The XRD patterns of $\mathrm{Ti}\left(\mathrm{SO}_{4}\right)_{2} / \mathrm{TiO}_{2}$ containing different titanium sulfate contents and calcined at $300^{\circ} \mathrm{C}$ for $2 \mathrm{~h}$ are shown in Figure 5. No diffraction lines of titanium sulfate are observed at low $\mathrm{Ti}\left(\mathrm{SO}_{4}\right)_{2}$ loading up to $30 \mathrm{wt} \%$, indicating good dispersion of $\mathrm{Ti}\left(\mathrm{SO}_{4}\right)_{2}$ on the surface of $\mathrm{TiO}_{2}$. For all $\mathrm{Ti}\left(\mathrm{SO}_{4}\right)_{2} / \mathrm{TiO}_{2}$ samples, only anatase phase $\mathrm{TiO}_{2}$ was observed at their calcination temperature $300{ }^{\circ} \mathrm{C}$, indicating that the phase transition of $\mathrm{TiO}_{2}$ from anatase form to rutile is difficult due to the interaction between $\mathrm{Ti}\left(\mathrm{SO}_{4}\right)_{2}$ and $\mathrm{TiO}_{2}$. However, as shown in Figure 6 , the higher is the content of $\mathrm{Ti}\left(\mathrm{SO}_{4}\right)_{2}$, the lower is the amount of anatase phase for $\mathrm{TiO}_{2}$. because the interaction between them prevents the phase transition from amorphous phase to anatase..$^{25}$

Thermal analysis. To examine the thermal properties of precursors of $\mathrm{Ti}^{\mathrm{T}}\left(\mathrm{SO}_{4}\right)_{2} / \mathrm{TiO}$, samples more clearly, thermal analysis has been carried out and the results are illustrated in Figure 6. For pure li $\left(\mathrm{SO}_{4}\right)_{2} \cdot 4 \mathrm{H}_{2} \mathrm{O}$ occurs in four steps. The endothermic two peaks around 567 and $630{ }^{\circ} \mathrm{C}$ are due to the evolution of $\mathrm{SO}_{3}$ decomposed from titanium sulfate. ${ }^{3 ;}$ litanium sulfate begins to decompose around $550{ }^{\circ} \mathrm{C}$ and the decomposition occurs by two steps, as shown in rigure 6.

However, for $\left[\mathrm{Ii}\left(\mathrm{SO}_{4}\right)_{2} / \mathrm{IiO}_{2}\right.$ samples, the $\mathrm{DSC}$ patterns are somewhat different from that of $\mathrm{li}\left(\mathrm{SO}_{4}\right)_{2} \cdot 4 \mathrm{H}_{2} \mathrm{O}$. For $\mathrm{Ti}\left(\mathrm{SO}_{4}\right)_{2}$ ' $\mathrm{IiO}_{2}$ samples, the DSC curve showed endothermic peaks below 200 " $\mathrm{C}$ due to the elimination of adsorbed water and hydrated water, and the endothermic peaks around 567 and $630{ }^{\circ} \mathrm{C}$ due to the evolution of $\mathrm{SO}_{3}$ decomposed from the sulfate ion bonded to the surface of $\mathrm{TiO}_{2},{ }^{3.3}$ Namely, the 
Table 1. Specific surface area and acidity of $\mathrm{Ti}_{(\mathrm{SO}} \mathrm{SO}_{2} / \mathrm{TiO}_{2}$ calcined al $300^{\circ} \mathrm{C}$. for $2 \mathrm{~h}$

\begin{tabular}{|c|c|c|}
\hline Calalyst & $\begin{array}{l}\text { Specific surface area } \\
\qquad\left(\mathrm{m}^{2} / \mathrm{g}\right)\end{array}$ & Acidily ( $\mu$ molig) \\
\hline $\mathrm{TiO}_{2}$ & 138 & 321 \\
\hline $5-\mathrm{Ti}\left(\mathrm{SO}_{4}\right)_{2} / \mathrm{TiO}_{2}$ & 226 & 436 \\
\hline $10-\mathrm{Ti}\left(\mathrm{SO}_{4}\right)_{2} / \mathrm{TiO}_{2}$ & 260 & 477 \\
\hline $15-\mathrm{Ti}_{(}\left(\mathrm{SO}_{4}\right)_{2} / \mathrm{TiO}_{2}$ & 248 & 511 \\
\hline $20-\mathrm{Ti}\left(\mathrm{SO}_{4}\right)_{2} / \mathrm{TiO}_{2}$ & 193 & 557 \\
\hline $25-\mathrm{Ti}\left(\mathrm{SO}_{4}\right)_{2} / \mathrm{TiO}_{2}$ & 88 & 518 \\
\hline $30-\mathrm{Ti}\left(\mathrm{SO}_{4}\right)_{2} / \mathrm{TiO}_{2}$ & 21 & 295 \\
\hline
\end{tabular}

Table 2. Specific surlace area and acidity of $20-\mathrm{Ti}\left(\mathrm{SO}_{4}\right) / 2 \mathrm{TiO}$ calcined at difterent temperatures for $2 \mathrm{~h}$

\begin{tabular}{ccc}
\hline $\begin{array}{c}\text { Cacination } \\
\text { tempcrature } \\
\left({ }^{\circ} \mathrm{C}\right)\end{array}$ & $\begin{array}{c}\text { Specific surlace area } \\
\left(\mathrm{m}^{2} / \mathrm{g}\right)\end{array}$ & $\begin{array}{c}\text { Acidity } \\
(\mu \mathrm{mol}) \mathrm{g})\end{array}$ \\
\hline 200 & 187 & 540 \\
300 & 193 & 557 \\
400 & 187 & 385 \\
500 & 163 & 274 \\
600 & 104 & 167 \\
700 & 33 & 53 \\
800 & 17 & 20 \\
\hline
\end{tabular}

thermal stability of the sulfate ion bonded to the surface of $\mathrm{TiO}_{2}$ is the same as that of titanium sulfate. The thermal stability of the sulfate ion bonded to the surface of metal oxide support is different depending on the kind of metal oxide. In the case of $\mathrm{NiSO}_{4} / \mathrm{Al}_{2} \mathrm{O}_{3}$ samples reported previously, two endothermic peaks are observed around 785 and $829^{\circ} \mathrm{C}$ due to the evolution of $\mathrm{SO}_{\text {s. }}$, showing that sulfated species with different thermal stability are present in the samples. ${ }^{32}$

Surface properties. The specific surface areas of samples calcined at $300^{\circ} \mathrm{C}$ for $2 \mathrm{~h}$ are listed in Table 1 . The presence of titanium sulfate influences the surface area in comparison with the pure $\mathrm{CiO}_{2}$. Specific surface areas of $\mathrm{I} i\left(\mathrm{SO}_{4}\right)_{2} / \mathrm{liO}_{2}$ samples are larger than that of pure $\mathrm{IiO}_{2}$ calcined at the same temperature, showing that surface area increases gradually with increasing titanitum sulfate loading up to 10 $w t \%$. It seems likely that the interaction between titanium sulfate and $\mathrm{TiO}_{2}$ prevents catalysts from crystallizing. ${ }^{22,25}$ The decrease of surface area for $\left[\mathrm{i}\left(\mathrm{SO}_{4}\right)_{2} / \mathrm{IiO}_{2}\right.$ samples containing li( $\left(\mathrm{SO}_{4}\right)_{2}$ above $10 \mathrm{wt} \%$ is due to the block of $\mathrm{JiO}_{2}$ pore by the increased $\mathrm{li}\left(\mathrm{SO}_{4}\right)_{2}$ loading. The acidity of catalysts calcined at $300^{\circ} \mathrm{C}$. as determined by the amount of $\mathrm{NH}_{3}$ irreversibly adsorbed at $230^{\circ} \mathrm{C},{ }^{23.34}$ is listed in lable 1. The acidity increases with increasing titanium sulfate content up to $20 \mathrm{wt} \%$ of $\mathrm{li}\left(\mathrm{SO}_{4}\right)_{2}$. The acidity is correlated with the catalytic activity for acid catalysis discussed below.

The specific surface area of $20-\mathrm{l} \mathrm{i}\left(\mathrm{SO}_{4}\right)_{2} /\left[\mathrm{IO}_{2}\right.$ calcined at different temperature are also listed in lable 2 . Both values exhibited maxima for the sample calcined at $300{ }^{\circ} \mathrm{C}$. In general, the crystallinity influences on the surface area and acidity of catalyst. ${ }^{35}$ As shown in Figure 4 , the amount of

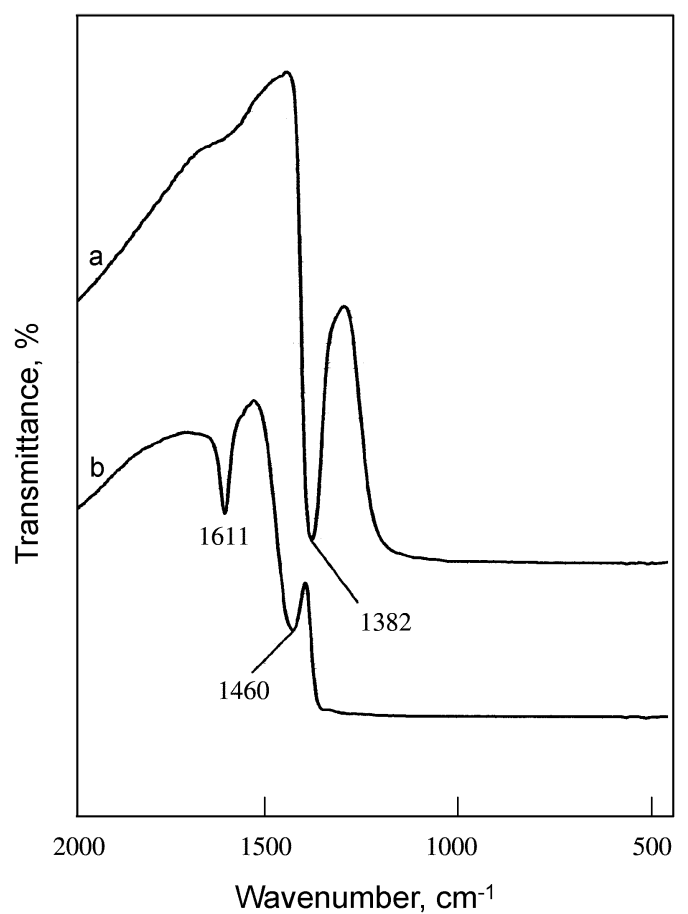

Figure 7. Infirared spectra of $\mathrm{NH}_{3}$ adsorhed on $20-\mathrm{Ti}\left(\mathrm{SO}_{4}\right)_{2} / \mathrm{TiO}_{2}$ : (a) background of 20 - $\mathrm{Ti}_{2}\left(\mathrm{SO}_{4}\right)_{2} \mathrm{TiO}_{2}$ evacuated at $500^{\circ} \mathrm{C}$ for $1 \mathrm{~h}$ (b) ammonia (20 lorr) adsorbed on (a); gas phase evacuated at $230^{\circ} \mathrm{C}$. for I h.

crystalline material increases with increasing the calcination temperature. Therefore, the decreases for both surface area and acidity of $20-\mathrm{Ti}\left(\mathrm{SO}_{4}\right)_{2} / \mathrm{TiO}_{2}$ above $300^{\circ} \mathrm{C}$ are due to the increasing amount of crystalline material at high temperature.

Infrared spectroscopic studies of ammonia adsorbed on solid surfaces have made it possible to distinguish between Brönsted and I ewis acid sites, ${ }^{22.32 .36}$ Figure 7 shows the IR spectra of ammonia adsorbed on 20-Ti( $\left.\mathrm{SO}_{4}\right)_{2} / \mathrm{TiO}_{2}$ samples evacuated at $500{ }^{\circ} \mathrm{C}$ for $1 \mathrm{~h}$. For $20-\mathrm{Ti}\left(\mathrm{SO}_{4}\right)_{2} / \mathrm{TiO}_{2}$ the band at $1460 \mathrm{~cm}^{-1}$ is the characteristic peak of ammonium ion. which is formed on the Brönsted acid sites and the absorption peak at $161 \mathrm{l} \mathrm{cm}^{-1}$ is contributed by amınonia coordinately bonded to Lewis acid sites, 22.32 .36 indicating the presence of both Brönsted and Lewis acid sites on the surface of $20-\left[\mathrm{i}\left(\mathrm{SO}_{4}\right)_{2} / \mathrm{CiO}_{2}\right.$ sample. Other samples having different titanium sulfate content also showed the presence of both Lewis and Brönsted acids. The intense band at 1382 $\mathrm{cm}^{-1}$ after evacuation at $500{ }^{\circ} \mathrm{C}$ is assigned to the asymmetric stretching vibration of $\mathrm{S}=\mathrm{O}$ bonds having a high double bond nature..$^{30.37}$ However, the drastic shift of the IR band from $1382 \mathrm{~cm}^{-1}$ to lower wavenumber (not shown due to the overlaps with skeletal vibration bands of $\mathrm{liO}_{2}$ ) after ammonia adsorption [Figure $7(\mathrm{~B})$ ] indicates a strong interaction between an adsorbed ammonia molecule and the surface complex. Namely, the surface sulfur compound in the highly acidic catalysts has a strong tendency to reduce the bond order of $\mathrm{SO}$ from a highly covalent double-bond character to a lesser double-bond character when a basic ammonia molecule is adsorbed on the catalysts..$^{30.32}$ 


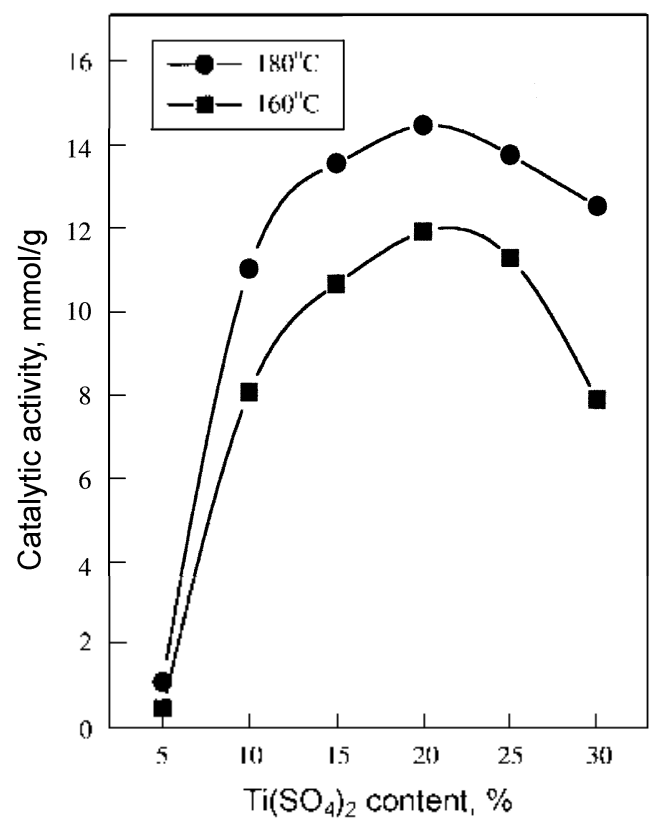

Figure 8. Calalytic aclivities of $\mathrm{Ti}\left(\mathrm{SO}_{1}\right)_{2} / \mathrm{IiO}_{2}$ lor 2-propanol dehydration as a function of $\mathrm{li}\left(\mathrm{SO}_{4}\right)_{2}$ content.

Acid stronger than $\mathrm{H}_{0} \leq-11.93$, which corresponds to the acid strength of $100 \% \mathrm{H}_{2} \mathrm{SO}_{4}$, are superacids. ${ }^{1.2 .4 .38}$ The strong ability of the sulfur complex to accommodate electrons from a basic molecule such as ammonia is a driving force to generate superacidic properties..$^{30.37}$ The $1390-1370$ bands representing the asymmetric stretching of $S=O$ is often regarded as the characteristic band of sulfated superacids. ${ }^{3.36}$ As shown in Figure 2, the asymmetric stretching bands of $\mathrm{S}=\mathrm{O}$ after evacuation at $100-500^{\circ} \mathrm{C}$ appeared at $1370-1382 \mathrm{~cm}^{-1}$ differently depending on the evacuation temperature. The acid strength of $\mathrm{Ti}\left(\mathrm{SO}_{4}\right)_{2} / \mathrm{TiO}_{2}$ samples

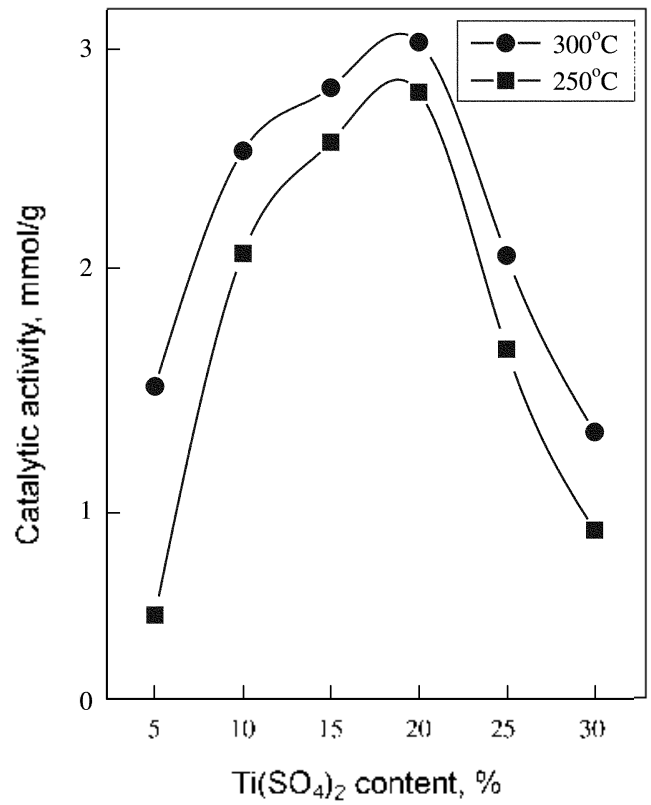

Figure 9. Catalytic activities of $\mathrm{Ii}\left(\mathrm{SO}_{4}\right)_{2} / \mathrm{TiO}_{2}$ for cumene dealkylation as a function of $\mathrm{Ti}\left(\mathrm{SO}_{4}\right)_{2}$ content.

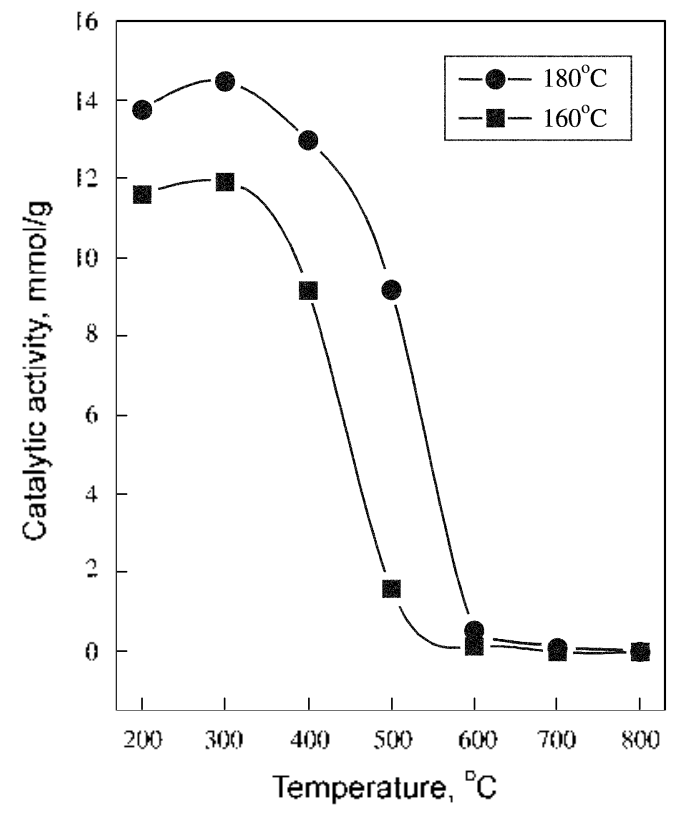

Figure 10. Catalytic activities of $20-\mathrm{Ti}\left(\mathrm{SO}_{4}\right)_{2} / \mathrm{TiO}_{2}$ for 2 -propanol dehydration as a function of calcination temperature.

after evacuation at $400{ }^{\circ} \mathrm{C}$ for $1 \mathrm{~h}$ was also examined by a color change method, using Hammet indicator ${ }^{10.11}$ in sulfuryl chloride. The samples were estimated to have $H_{1} \leq-14.5$, indicating the formation of superacidic sites. Consequently, $\mathrm{Ti}\left(\mathrm{SO}_{4}\right)_{2} / \mathrm{TiO}_{2}$ catalysts would be solid superacids, in analogy with the case of $\mathrm{TiO}_{2}$ modified with sulfate group. ${ }^{27}$

Catalytic activities for acid catalysis. The catalytic activities for the 2-propanol dehydration are measured and the results are illustrated as a function of $\mathrm{Ti}\left(\mathrm{SO}_{4}\right)_{2}$ content in Figure 8, where reaction temperatures are $160-180$ " $\mathrm{C}$. In view of Table 1 and Figure 8 , the variations in catalytic activity for 2-propanol dehydration are well correlated with the changes of their acidity, showing the highest activity and acidity for $20-\mathrm{Ti}\left(\mathrm{SO}_{4}\right)_{2} / \mathrm{TiO}_{2}$. It has been known that 2propanol dehydration takes place very readily on weak acid sites. $^{\text {4i.t4 }}$ Good correlations have been found in many cases between the acidity and the catalytic activities of solid acids. For example the rates of both the catalytic decomposition of cumene and the polymerization of propylene over $\mathrm{SiO}_{2}$ $\mathrm{Al}_{2} \mathrm{O}_{3}$ catalysts were found to increase with increasing acid amounts at strength $\mathrm{H}_{0} \leq+3.3 .^{35}$ It was also reported that the catalytic activity of nickel silicates in the ethylene dimerization as well as in the butene isomerization was closely correlated with the acidity of the catalyst. ${ }^{+5.40}$

Cumene dealkylation takes place on relatively strong acid sites of the catalysts. ${ }^{4.44}$ Catalytic activities for cumene dealkylation against $\mathrm{l} i\left(\mathrm{SO}_{4}\right)_{2}$ content are presented in Figure 9. where reaction temperature is $250-300{ }^{\circ} \mathrm{C}$. Examining lable 1 and Figure 9, the catalytic activities are also correlated with the acidity. The correlation between catalytic activity and acidity holds for both reactions, cumene dealkylation and 2-propanol dehydration, although the acid strength required to catalyze acid reaction is different depending on the type of reactions. As seen in Figures 8 and 


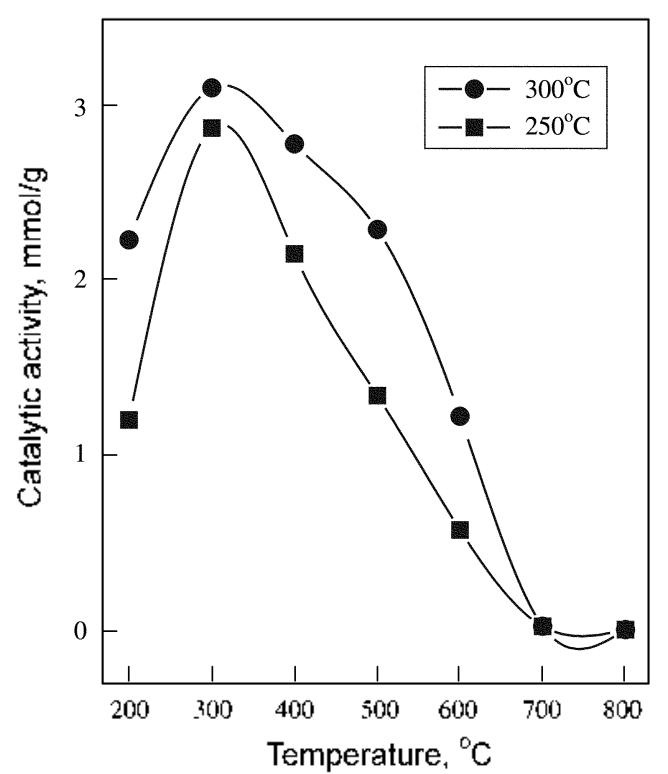

Figure 11. Catalytic activitics of 20 - $\mathrm{Ti}\left(\mathrm{SO}_{4}\right)_{2} / \mathrm{TiO}_{2}$ for cumene dealkylation as a lunction of calcination temperature.

9, the catalytic activity for cumene dealkylation, in spite of higher reaction temperature, is lower than that for 2-propanol dehydration.

Catalytic activities of $20-\mathrm{Ti}\left(\mathrm{SO}_{4}\right)_{2} / \mathrm{TiO}_{2}$ for 2-propanol dehydration are plotted as a function of calcination temperature in Figure 10. The activities increased with the calcination temperature, giving a maximum at $300^{\circ} \mathrm{C}$ and then the activities decreased. Catalytic activities of $20-\mathrm{Ti}\left(\mathrm{SO}_{4}\right)_{2} /$ $\mathrm{TiO}_{2}$ for cumene dealkylation are also plotted as a function of calcination temperature in Figure 11. The activities also exhibited a maximum at $300^{\circ} \mathrm{C}$. The deceased of activity for both reaction above $300^{\circ} \mathrm{C}$ can be probably attributed to the fact that the surface area and acidity above $300{ }^{\circ} \mathrm{C}$ decrease with the calcination temperature. Considering the experimental results of Table 2, and Figures 10 and 11 . it is clear that the catalytic activities for both reactions are correlated with the acidity of catalysts.

\section{Conclusions}

This paper has demonotrated that a combination of FIIR. DSC, and XRD can be used to conduct the characterization of $\mathrm{li}\left(\mathrm{SO}_{4}\right)_{2} /\left[\mathrm{iO}_{2}\right.$ prepared by impregnation of powdered $\mathrm{li}(\mathrm{OH})_{4}$ with titanium sulfate aqueous solution followed by calcining in air. The acidity of catalysts increase in proportion to the titanium sulfate content up to $20 \mathrm{wt} \%$ of $\mathrm{l}$ i $\left(\mathrm{SO}_{4}\right)_{2}$. The acid strength of $\mathrm{I} /\left(\mathrm{SO}_{4}\right)_{2} / \mathrm{liO}_{2}$ samples was estimated to have $H_{0} \leq-14.5$, indicating the formation of superacidic sites. The correlation between catalytic activity and acidity holds for both reactions, cumene dealkylation and 2propanol dehydration.

Acknowledgements. This work was supported by grant No. (R05-2003-000-10074-0) from the Basic Research Program of the Korea Science and Engineering Foundation.
We wish to thank Korea Basic Science Institute (Daegu Branch) for the use of X-ray diffractometer.

\section{References}

1. Cheung. T. K.: d'Itri, J, I., I ange. F, C.: Gates. B, C. Catal. Lett. 1995. 31. 153.

2. Tanabe. K.: Misono. M.: Ono. Y.: Hatlori. H. Aew Sold leids and Bases: Elsevier Science: Amsterdarm. 1989: Chapter 4.

3. Olah. G. A.: Prakash. G. K. S.: Sommer. I. Stuperacids: WileyInterseience: New York. 1985: Chapter 2.

4. Arata K, Atlv (cuthl, 1990. 37. 165.

5. Sohn. I. R. J. Ind Eng Chem. 20104. /0. I.

6. Ward. D. A.: Ko. E. L. J. Catal. 1994. 150. 18.

7. vaudagna. S. R.: Comelli. R. A.: Canavese. S. A.: Figoli. N. S.J. (cuttl. 1997. 169. 389.

8. Kustow. I., M.: Kazansky. V. B.: Figulras. F.: Tichit. D. J. Catal. 1994.150 .143$.

9. Sayari. A.: Yang. Y.: Song. X. J. Catal. 1997. 167, 346.

10. Hsu. C. Y.: Heimbuch. C. R.: Armes. C. I: Gates. B. C. J. Chen. Soe. (hem. Commm. 1992. 1645.

11. Cheung. T. K.: Gates. B. C.J. (ctut. 1997. /68. 522.

12. Adeeva V.: de IJaan. II, W.: Janchen. J.: I.é. G. D.: Schunemann. V.: van de Ven. I., J. M.: Sachtler. W. M. II.: van Santen. R. A.J. Catchl. 1995. 15/. 364 .

13. Wan. K. J.: Khouw. C. B.: Davis. M. E. J. Catal. 1996. 158.311.

14. Song. X.: Reddy. K. R.: Sayari. A. J. Catal. 1996. J61. 206.

15. Coclho. V. A.: Resasco. D. E.: Sikabuc. E. C.: White. R. L. Cattl Lett. 1995. 32. 253.

16. Hosoi. T.: Shimadzu. T.: Ito. S.: Baba S.: Takaoka II.: Imai, T.: Yokoyama . . Prepr: Sinm. Div. Per: Chem: American Chemical Society: LosAngels. CA. 1988: $p 562$.

17. Ebitani. K.: Konishi. J.: Hallori. H. J. Catat. 1991. /30. 257.

18. Signoretto. V.: Pinna. F.: Strukul. G.: Chies. P.: Cerrato. G.: Ciero.S. D.: Morterra C. J. Catal. 1997. 167.522.

19. Hino. M.: Arata K. J. Chem. Soc: Chem. Commen. 1987, 1259.

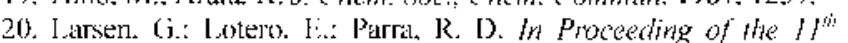
International Congress on Catalysis: Elsevier : New York. 1996 pp 543-551.

21. Arata. K.: Hino. M.: Yamagata. V. Buff. ( hem. Soc. Jpn. 1990. 63. 244.

23. Sohn, J. R.: Kwon, T. D.: Kim, S. B. J. Ind. Eng Chem. 2001, 7. 441.

23. Sohn. J. R.: Lee. I. S. Rull. Korean (hem Soc. 2003. 24. 159.

24. Sohn. I. R.: Park. W. C.: Kim. H. W. J. Catal. 2002. 2f9. 69.

25. Sohn. I. R.: Bac. J. H. Korten .f. (hem. ling. 2000. 17. 86.

26. Sohn. J. R.: Park. M. Y. Langmiar 1908. /f. 6140)

27. Sohn, J. R.: Kim, II, W.: Park, M. Y.: Park, F., H.: Kim, J. T.: Park. S. I: Appl. Catal. A: Generd 1995. 128. 127.

28. Saur. O.: Benstitel. M.: Saad. A. B. H.: Lavalley I. C.: Tripp. C. l': Morrow. B. A. J. Catal. 1986. 99. 104.

29. Morrow. B. A.: McFarlane. R. A.: Lion. M.: Lavalley. J, C. $J$. Catcl, 1987, 107, 232.

30. Yamaguchi. T. Appl. Catal. 1990.61, 1.

31. Jin. T:: Yamaguchi. I.: lananbe. K. J. Plas. Chem. 1986. 90. 4794.

32. Sohn. I. R.: Park. W. C. Appl. Catal A. General 2003. 239. 269.

33. Hua. W.: Xia. Y.: Yue. Y.: Gao. Z.J. ('atal, 2000. 196. 104.

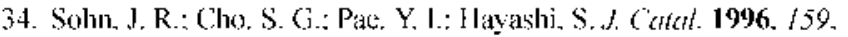
170 .

35. Tanabe. K. Sold foids and Bases: Kodansha Tisyo. 1970: p 170.

36. Satsuma. A.: Hatori. A.: Mizutani. K.: Furuta. A.: MiyaMoto. A.: Hattori. l.: Murakani. Y. J. Phes. (hen. 1988. 92. 6052.

37. Sohn. J. R.: Park. E. H.: Kim. H. W. J. Ind ling ('hem. 1999. 5. 253 .

38. Olah. F. G. A.: Prakash. G. K. S.: Sommer J. Sience 1979. 266. 13. 
39. Miao. C.: Hua. W.: Chen. J.: Gao. Z. Gatal. Lett. 1996. 37. 187.

40. Sohn. J. R.: Ryu. S. G. Lamgmir 1993. 9. 126.

41. Solm, J. R: Lee, S. Y. Appt Catal A: Genteral 1997. 164, 127.

42. Solm. J. R. Jang. H. J. Hol Cotol 1991. 64, 349.

43. Decanio, S. J. Solnn, J. R. Paul. P. O.: Lunsford, J. H. J. Catal.
1986. 101. 132.

44. Sohn1. I. R.: Chun. E. W.: Pae. Y. I. Bull. Koman Chem. Soc. 2003. 24. 1785.

45. Sohn. J. R.: Ozaki. A. J. Catal. 1980, 61. 29.

46. Sohn. J. R. Park. W. C. Kim, H. W. J. Catal. 2002, 209,69. 